\title{
Effect of scarification on soil change and establishment of and artificial forest regeneration under Nothofagus spp. in Southern Chile
}

\author{
J. Reyes ${ }^{1,2}$, O. Thiers ${ }^{1,2^{*}}$, V. Gerding ${ }^{1,2}$, P. Donoso ${ }^{1}$ \\ ${ }^{1}$ Universidad Austral de Chile, Facultad de Ciencias Forestales y Recursos Naturales. C. P. 5090000. Valdivia, Chile. ${ }^{2}$ Universidad \\ Austral de Chile, Centro de Investigación en Suelos Volcánicos-CISVo. C. P. 5090000. Valdivia, Chile. "Corresponding author: \\ othiers@uach.cl
}

\begin{abstract}
Soil scarification has been used as a silvicultural method to facilitate the regeneration of some forests, but it may have a negative impact on the properties of the soil. We evaluated the effect of a mechanized scarification on a volcanic soil after a shelterwood cutting in a Nothofagus spp. forest, located in the Andean region of southern Chile $\left(39^{\circ} 54\right.$ 'S, $71^{\circ} 56^{\prime} 5 \mathrm{~W}, 970 \mathrm{~m}$ asl). A plantation of Nothofagus nervosa was established after scarification, and its physical (moisture content, bulk density, penetration resistance) and chemical ( $\mathrm{pH}$, organic matter, macro and microelements; saturation $\mathrm{Al}$ ) soil properties were analyzed in scarified gaps and undisturbed forest. The size of N. nervosa planted trees was measured eleven months after their establishment (June 2010). The volumetric water content of the soil was similar with and without scarification (30-50\%), regardless of the time of year. The bulk density was higher in the scarified soil when compared to the undisturbed forest. The soil nutrient supply in the gaps $(0-20 \mathrm{~cm})$ decreased when compared to the undisturbed forest $(0-10 \mathrm{~cm})$, but showed little difference between gaps and between locations within them. The $N$. nervosa plantation developed properly, with similar growth in gaps of different size. Scarification decreased soil quality; the effects on regeneration will need further evaluation throughout a longer period.
\end{abstract}

Keywords: Silviculture, soil scarification, physical and chemical soil properties, Nothofagus forests

\section{Introduction}

Nothofagus spp. forests in Chile have been used for timber along their history. An example are the forests in the Andes of southern Chile, which have been altered by the action of logging (mainly concentrated in Nothofagus nervosa (Phil.) Dimitri et Milano), forest fires (man-caused) and, sometimes, by natural disasters (landslides, volcanic eruptions, tree falls).
In the past, a regular practice was continuous selective logging or "floreos" (extraction of the best individuals) without considering silvicultural aspects for their subsequent regeneration. These actions have left degraded forests, making them hard to find in their original state nowadays (Donoso and Lara, 1995; Otero, 2006). 
In order to carry out the recovery of these forests, further studies are needed on different silvicultural systems that might facilitate re-establishment, considering their effectiveness and the impact they may have on the site (Nyland, 2002). One alternative is the shelterwood system, which removes gradually the stand in a series of partial cuttings to produce an even-aged stand through natural regeneration, which develops under the protection of the old stand (Nyland, 2002; Röhrig et al., 2006).

Among the silvicultural practices that facilitate forest regeneration, usually after a cutting, is soil scarification (Nyland, 2002). This technique plows or remove a surface layer of the soil and litter in order to mitigate or eliminate competition for light, water and nutrients, as well as to improve the soil and environmental conditions to favor the establishment of forest species of interest (Örlander et al., 1996; Resco de Dios et al., 2005; Yoshida et al., 2005; Aoyama et al., 2009). The soil scarification has been commonly used in boreal forests or low temperatures forests (where the soil is covered by a thick litter), succeding as a technique that facilitates natural regeneration, in both density and performance, and in some cases to achieve even-aged and monospecifics stands (Wurtz and Zasada, 2001; Zaczek et al., 2002; Hille and den Ouden, 2004; Karlson and Nilson, 2005; Yoshida et al., 2005). However, the removal of soil can have negative effects on its properties when a mineral soil is exposed, which is less fertile and can increase erosion and nutrient leaching (Palviainen et al., 2005; Piirainen et al., 2007). These effects vary according to the size and intensity of the intervention area (Gastaldello et al., 2007). The carbon balance is uncertain, although the intervened area is the edafic zone with more accumulation in the soil, it is expected that the establishment of a new regeneration will create an area of carbon reserve, although the time factor must be considered (Aoyama et al., 2011).

In the case of the Andean forests of southern Chile, scarification would favor the establishment of Nothofagus species, given their autecological feature of low tolerance to shade that prevents regeneration in case of dense undergrowth. In the region of the Andes, Nothofagus spp. have regenerated mainly after coarsescale disturbances such as volcanic and tectonic activity, snow avalanches, fire, blowdown, and those associated to glaciers process. The small-scale disturbances like treefall gaps have less importance. In the absence of coarse-scale disturbances, these species are replaced by shade-tolerant species, as what happens in the Coastal Range of the southern Chile. The disruption caused by some of these disturbances, such as landslides, creates open areas without forest and with exposed mineral soil (often have partial or total loss of A and B horizons) to whom arrive seeds from nearby locations for a new establishment of regeneration. This is known as catastrophic regeneration mode (Veblen et al., 1996). Soil scarification simulates conditions that are similar to those generated by coarse-scale disturbances.

Moreover, there is a high presence in these forests of Chusquea bamboos which colonize areas with some canopy opening, being Chusquea culeou E. Desv. the predominant species in Andean areas. Pearson et al. (1994) found a high accumulation of biomass of this species (150 $\mathrm{Mg} \mathrm{ha}^{-1}$ dry live matter) in forests of southern Argentina, containing 33\% of roots and rhizomes located in the first $20-30 \mathrm{~cm}$ depth. This large amount of biomass in the topsoil difficults the establishment of other species, so silvicultural interventions are needed to facilitate the establishment of regeneration. A study on natural regeneration of $N$. nervosa in Chile (Donoso et al., 2006) reported that scarification improved the survival of this species (more than double compared to the non-intervened area) and, if accompanied by a shelterwood cutting, its height was increased compared to other treatments.

This study evaluates the effects of a mechanized scarification on the soil surface of a Nothofagus spp. forest in the Andes of southern Chile, after a shelterwood cutting. The hypothesis proposes that scarification have a negative effect on soil properties as depth, bulk density, penetration resistance and nutrient offer, resulting from the removal of topsoil, 
causing variations within the scarified area, but due to catastrophic regenerative dynamic of Nothofagus species, these conditions of soil are tolerable and the elimination of competence for light and resources helps to a better establishment. The objectives are to characterize the temporal and spatial variation of soil properties in scarified areas compared to the nonscarified forest, and to evaluate the growth of artificial regeneration of $N$. nervosa in the area of intervention.

\section{Material and Methods}

\subsection{Study area}

The study was conducted at the Pilmaiquén farm, Piedras Negras site (39 54' 42, 44" S, 71 56' 5,67' W, $970 \mathrm{~m}$ asl) in the Andes of southern Chile. The climate is Andean Polar, characteristic of high mountains outside the tropics, and the agroclimate is Central Cordillera (INIA, 1989). The average annual temperature is 11 ${ }^{\circ} \mathrm{C}$, with absolute minimum below $-5{ }^{\circ} \mathrm{C}$ and absolute maximum above $30^{\circ} \mathrm{C}$. Rainfall is around 3,000-3,500 $\mathrm{mm}$ per year, turning into snow during the winter above the level of $800 \mathrm{~m}$ asl. The soil has transition features between the Liquiñe (Acrudoxic Hapludand) and Choshuenco (Andic Dystrudept) series (CIREN 2001). The landform is high mountain, situated on a high hill with a slope of 5-10\%, preferably north exposure.

During the summer 2006-2007, a shelterwood cutting was carried out in a forest of the coihue-rauli-tepa type (Donoso, 1981). Table 1 shows the structure of original forest, the information was obtained from 10 rectangular plots of $500 \mathrm{~m}^{2}$. However, the intervention area was densely populated by the bamboo C. culeou and not with regeneration of Nothofagus spp., as expected. A mechanized scarification (Bulldozer Komatsu D4 with front end loader) was performed in March 2010, in eight hectares of forest. As a consequence of the scarification, 20 to $40 \mathrm{~cm}$ depth of mineral soil in gaps of different size were removed, as well as a litter of about $8 \pm 1 \mathrm{~cm}$ thick.
The removed material was placed in the periphery of the scarified area at a maximum distance of about 20 $\mathrm{m}$ from the center in larger gaps. This process aimed to remove $C$. couleou from the root, considering that this species can regrow vegetatively. A plantation of $N$. nervosa was established the first week of May 2010 in 30 gaps with scarified sectors, of 15 plants each. The plants had been grown in a nursery $(1 / 0)$ using $130 \mathrm{~cm}^{3}$ containers on a substrate of composted bark of Pinus radiata $\mathrm{D}$. Don, mixed with controlled release fertilizers (Bustos et al., 2008). The plants showed an initial height of $21 \mathrm{~cm} \pm 6 \mathrm{~cm}$ and a neck diameter of 3-4 $\mathrm{mm}$.

\subsection{Design and evaluation method}

Sampling of soil.

There was different sizes of gaps in the forest: small $\left(150-300 \mathrm{~m}^{2}\right)$, medium $\left(300-600 \mathrm{~m}^{2}\right)$ and large $(600-$ 1,000 $\mathrm{m}^{2}$ ). A gap of each size (small: $200 \mathrm{~m}^{2}$, medium: large $400 \mathrm{~m}^{2}$ and $750 \mathrm{~m}^{2}$ ) and an unditurbed forest area was selected, spaced approximately $50-100 \mathrm{~m}$ among them, were selected to sample soil properties. Soil moisture was measured only in the large gap (where there should be more variability) dividing it in different areas (edges, intermediate and center), according to the greater variation of direct sunlight, with five replicates each. Five measurements were made biweekly from February to April 2011. The lower rainfall season goes from mid summer to early fall, when you it is expect to find the minimum soil moisture content. Soil samples were extracted with 100 $\mathrm{cm}^{3}$ cylinders at two depths $(0-10 \mathrm{~cm}$ and $10-20 \mathrm{~cm}$, 25 samples per depth). This procedure was repeated in the undisturbed forest taking 10 samples per depth. Samples were also taken from the small and medium gaps using cylinders, but on one occasion (April 2011) they were taken with 15 replicates per depth at the edges and the center. Wherever a sample was taken, the penetration resistance was also measured using a pocket penetrometer (Soil-Test Model CL-700) vertically to the ground. Samples from the cylinders were dried at a temperature of $105{ }^{\circ} \mathrm{C}$, determining their bulk density. 
Table 1. Stand parameters of pre-scarified forest.

\begin{tabular}{lcccc}
\hline Especie & DBH $(\mathrm{cm})$ & Trees per hectare & Mean height $(\mathrm{m})$ & $\begin{array}{c}\text { Basal area } \\
\left(\mathrm{m}^{2} \mathrm{ha}^{-1}\right)\end{array}$ \\
\hline Nothofagus dombeyi & $94.9 \pm 34.3$ & $56 \pm 4.6$ & $36.5 \pm 4.0$ & $46.7 \pm 3.2$ \\
Nothofagus nervosa & $46.9 \pm 23.5$ & $29 \pm 2.7$ & $28.1 \pm 5.6$ & $6.8 \pm 0.8$ \\
Saxeghotaea conspicua & $28.7 \pm 8.1$ & $147 \pm 16.4$ & $21.6 \pm 6.5$ & $13.7 \pm 2.0$ \\
Total & - & 232 & - & 67.2 \\
\hline
\end{tabular}

In addition, gravimetric (weight/weight ratio) and volumetric water (gravimetric contended $\mathrm{x}$ bulk density) contents were determined in the larger gaps (Lal and Shukla, 2004).

Samples were also taken for chemical analysis according to the methodology of Schlatter et al. (2003) within the gaps, on the edges and central sectors, and also within the undisturbed forest. A mixed sample taken at three points for the top $20 \mathrm{~cm}$ was used for each situation. The undisturbed forest sampling was split in $0-10 \mathrm{~cm}$ and $10-20 \mathrm{~cm}$, considering that the surface had more influence of organic matter, whereas in the scarified area this condition was morphologically more homogeneous. The techniques utilized for soil chemical analysis were (Sadzawka et al., 2006): pH in distilled water and in $0.1 \mathrm{~N} \mathrm{KCl}$ solution in a ratio soil: solution $=1: 2.5$; phosphorus through Olsen extract, potassium, calcium, magnesium, sodium, iron, manganese, copper, zinc and aluminum (removable) in ammonium acetate extract at $\mathrm{pH}$ 4.8-DTPA; total carbon through oxidation with sodium dichromate and sulfuric acid; total nitrogen through Kjeldahl digestion; sulfur through calcium phosphate extract; exchangeable aluminum through $1 \mathrm{M} \mathrm{KCl}$ extract; and boron $0.15 \% \mathrm{CaCl}_{2}$ extract at boil for 5 minutes.

The variables penetration resistance and soil bulk density between the different gaps and the undisturbed forest were compared using One Way Analysis of Variance and Scheffé's Method of multi comparison of means to identify homogeneous groups $(p<0.05)$
(Zar, 2010). The moisture content was analyzed by Two-way Analysis of Variance (measurement date $\mathrm{x}$ location in the undisturbed forest and large gap). Data were transformed to logarithms to meet the assumptions of normality. A correlation analysis (Pearson coefficient, $p<0.01$ ) was also performed between the chemical-nutritional variables identified in the various sectors. As a complementary analysis, models of spatial distribution of the volumetric water content were made using the linear interpolation method of kriging (Haining, 2003).

Sampling of artificial regeneration.

There was no natural regeneration, therefore, the measurement was focused on the $N$. nervosa planting. The growth of all plants was measured in 15 gaps in May 2011, considering five gaps in each of the following sizes: small (150-300 $\left.\mathrm{m}^{2}\right)$, medium (300-600 $\mathrm{m}^{2}$ ) and large (600-1000 $\left.\mathrm{m}^{2}\right)$. Initial height of planted trees was also recorded for this plantation in June 2010, which did not differ significantly between the gaps at the time of establishment. Light availability in summer (early March 2011) was recorded under diffuse light conditions through hemispherical photographs captured in the center of each gap, using a Coolpix 4500 digital camera. The daily total light transmission index was obtained $\left(\mathrm{mol} \mathrm{m}^{-2}\right.$ day $\left.^{-1}\right)$ and the percentage of canopy opening (by using Gap Light Analyzer 2.0 software; Frazer et al. 1999). The variables measured in the plants were survival (\%), total height $(\mathrm{cm})$, root collar diameter $(\mathrm{mm})$ and volume (an elliptical cone 
was emulated through the following formula: $\pi / 6 \mathrm{x}$ root collar diameter ${ }^{2} \mathrm{x}$ total height ${ }^{2} ; \mathrm{cm}^{3}$ ), and it calculated the increase in height from establishment until 11 months of growth. A One-way Analysis of Variance (gap size) was performed for each one of these variables and Scheffés Method of multi comparison of means $(p<0.05)$ (Zar, 2010).

\section{Results}

\subsection{Physical properties of the soil}

The gravimetric soil water content at $0-10 \mathrm{~cm}$ depth was higher in the undisturbed forest $(129 \pm 18 \%)$ than in the large gap ( $49 \pm 9 \%)$, but there were no differences between locations within the gap. At 10-20 cm depth, gravimetric water content was similar between the undisturbed forest and the gap $(40 \pm 3 \%)$. There were no significant changes between measurement dates at both depths. Overall, there was no significant change in volumetric water content (Figure 1), with similar values $(30-50 \%)$ between the undisturbed forest and the different areas of the large gap for both depths, although in some cases it was higher the gap when compared to the undisturbed forest $(p<0.05)$. Statistically, only the third measurement date showed lower volumetric water compared to the others, in both the undisturbed forest and the gap $(p<0.05)$. There was no interaction between location and the measurement date. In large gap, the SW showed lower humidity values ranging from $30-40 \%$ (Figure 2 ) from the start of the measurements. This area is the most exposed to direct sunlight during most of the day. In the center of the gap there was no constant behavior.

The soil bulk density was significantly higher $(p<0.05)$ in the gaps when compared to the undisturbed forest, at both depths, and had lower differences between locations within the gaps (Figure 3). The penetration resistance was also higher $(p<0.05)$ when compared to the undisturbed forest (Figure 3). At $0-10 \mathrm{~cm}$ the undisturbed forest had lower values than those registered by the penetrometer $(<0.3 \mathrm{MPa})$, while scarified areas reached values of $0.5-1.0 \mathrm{MPa}$. At $10-20 \mathrm{~cm}$ the values were similar in both situations (0.5-1.0 MPa).

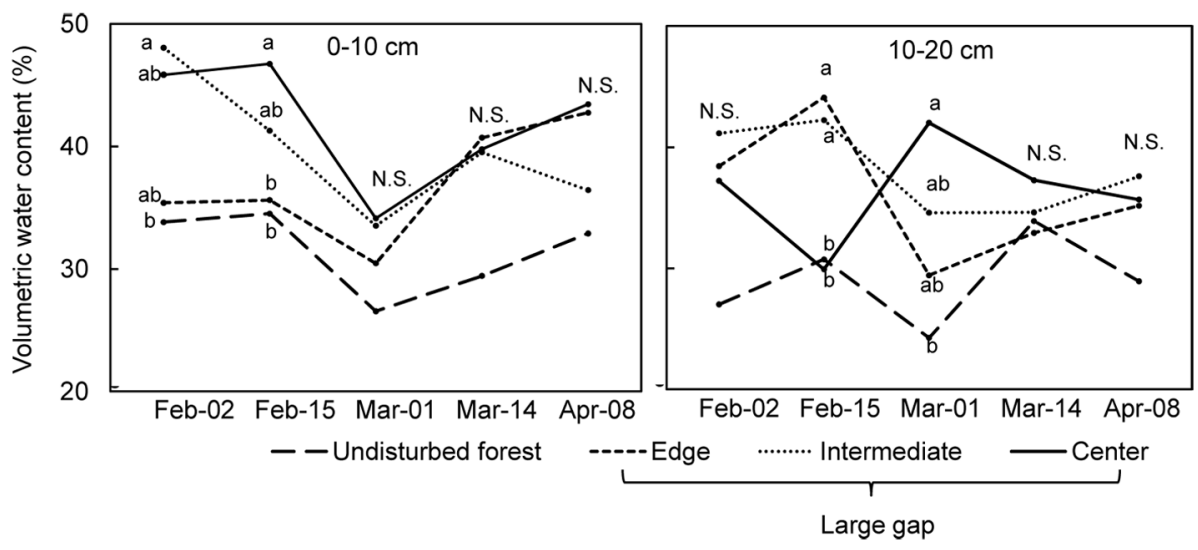

Figure 1. Volumetric water content (\%) according to their location in the large gap and the undisturbed forest. Different letters indicate significant differences between locations for each measurement date $(p<0.05)$. N. S.: no significant differences. 


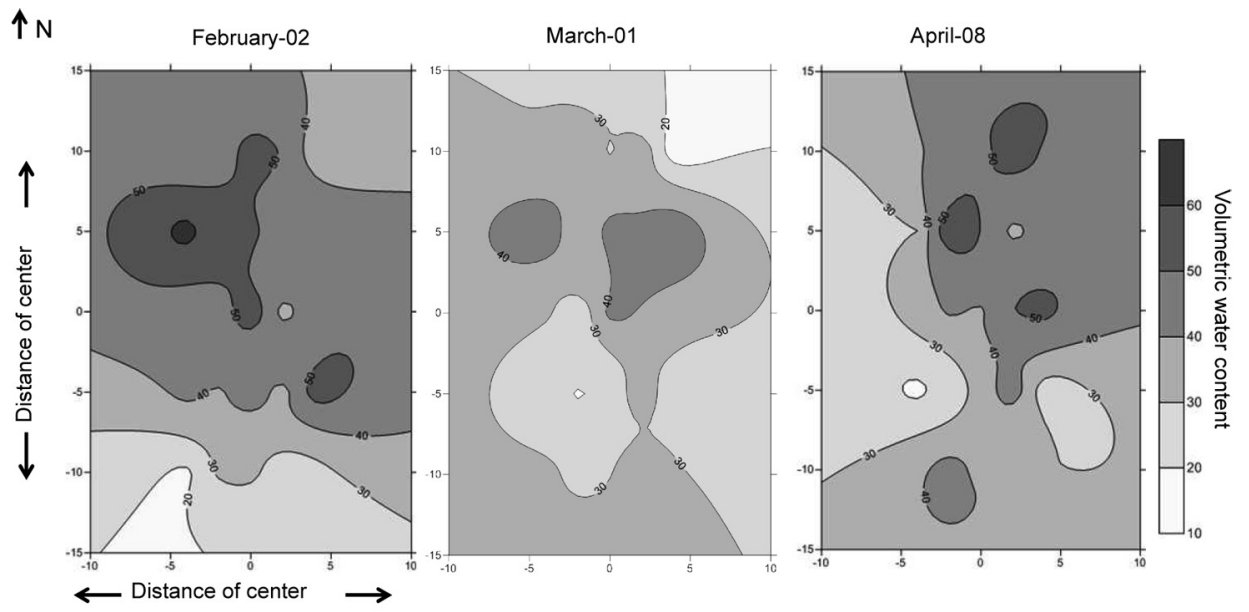

Figure 2. Volumetric water content (\%) in the first $10 \mathrm{~cm}$ into the large gap in three measurements.

\subsection{Chemical characteristics of the soil}

At $0-10 \mathrm{~cm}$ soil depth of the undisturbed forest there are high levels of organic matter, calcium and available phosphorus and very low aluminum saturation. In this soil, it was observed a strong decrease of nutrient content in the scarified areas (Table 2). The nutrient levels decreased in the $10-20 \mathrm{~cm}$ depth layer of the undisturbed forest, although they remained higher than the contents of the scarified sector. In this sense, the gaps did not vary significantly between them. However, in the large gaps there was a greater decrease in fertility factors of the soil, compared with the smaller gaps (see Table 2). The organic matter content showed a positive correlation $(p<0.01)$ with levels of nitrogen $(r=0.99)$, phosphorus $(\mathrm{r}=0.95)$, potassium $(\mathrm{r}=0.93)$, calcium $(\mathrm{r}=$ $0.99)$, magnesium $(r=0.96)$, iron $(r=0.99)$, manganese $(r=0.97)$, copper $(r=0.87)$, zinc $(r=0.98)$ and boron $(\mathrm{r}=0.86)$. The $\mathrm{pH}$ of the soil was strongly acidic (5.1$5.5)$, except in the large gap and the edge of the small gap where it was moderately acid (5.6 to 5.7). The sum of bases in the gaps decreased in the first $10 \mathrm{~cm}$ depth of the undisturbed forest floor (Table 2); aluminum saturation behaved inversely (Table 2), reaching higher values in scarified areas (15-38\%) when compared to the undisturbed forest $(1.2 \%$ at $0-10 \mathrm{~cm})$.

\subsection{Survival and growth of the plantation}

One year after the scarification, there was no natural regeneration of Nothofagus spp. or other tree species in the scarified gaps. The plantation of $N$. nervosa had a high survival (96-98\%) and its growth presented some differences according to the size of the gaps (Table 3). In the smaller gaps, the plants had a higher increase in height since their establishment when compared to other gaps $(p<0.05)$, and they were higher in total height when compared to medium gaps $(p<0.05)$. Instead, the root collar diameter was greater in large gaps when compared to other gaps $(p<0.05)$. The average volume of the plants was higher in larger gaps compared to medium gaps $(p<0.05)$.

\section{Discussion}

\subsection{Effect of scarification on the soil}

The soil characteristics of scarified areas are different from the undisturbed forest soil. 

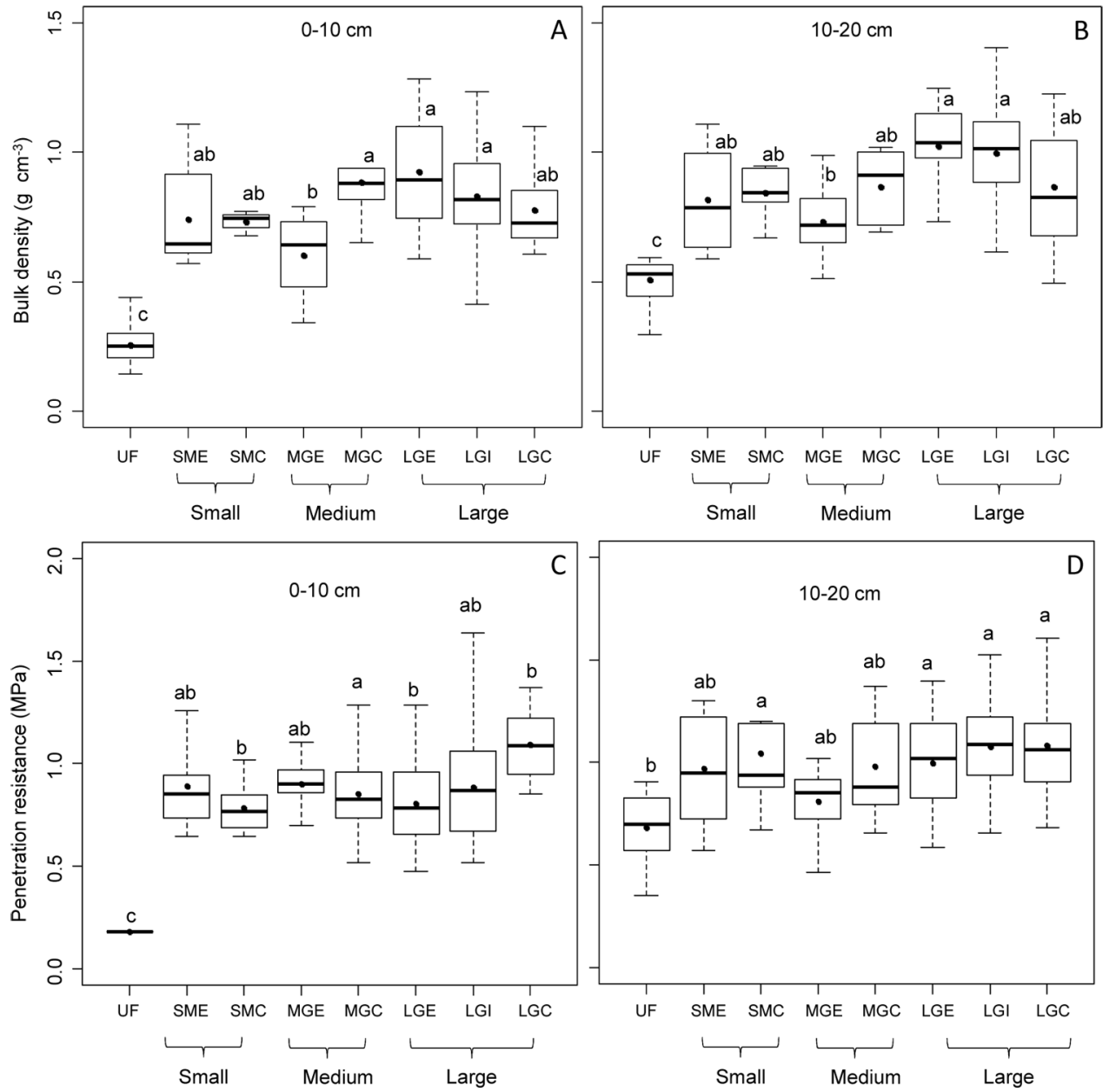

Figure 3. Soil bulk density at $0-10 \mathrm{~cm}(\mathrm{~A})$ and $10-20 \mathrm{~cm}(\mathrm{~B})$, and penetration resistance of $0-10 \mathrm{~cm}(\mathrm{C})$ and $10-20$ $\mathrm{cm}$ (D), according to its location in the gaps and undisturbed forest. UF: undisturbed forest; SGE: small gap edge; SGC: small gap center; MGE: medium gap edge; MGC: medium gap center; LGE: large gap edge; LGI: large gap intermediate; LGC: large gap center. Black dots indicate the arithmetic mean. Different letters differ significantly $(p<0.05)$ within each depth range. 
Table 2. Chemical analysis of soil according to location on undisturbed forest and gaps.

\begin{tabular}{|c|c|c|c|c|c|c|c|c|}
\hline \multirow[t]{3}{*}{ Parameter } & \multirow{2}{*}{\multicolumn{2}{|c|}{ Undisturbed forest }} & \multicolumn{2}{|c|}{$\begin{array}{c}\text { Small gap } \\
\left(200 \mathrm{~m}^{2}\right)\end{array}$} & \multicolumn{2}{|c|}{$\begin{array}{l}\text { Medium gap } \\
\left(400 \mathrm{~m}^{2}\right)\end{array}$} & \multicolumn{2}{|c|}{$\begin{array}{c}\text { Large gap } \\
\left(750 \mathrm{~m}^{2}\right)\end{array}$} \\
\hline & & & Edge & Center & Edge & Center & Edge & Center \\
\hline & $(0-10 \mathrm{~cm})$ & $(10-20 \mathrm{~cm})$ & \multicolumn{6}{|c|}{$(0-20 \mathrm{~cm})$} \\
\hline Soil organic matter (\%) & 36.7 & 12.0 & 4.0 & 10.1 & 11.1 & 8.3 & 7.6 & 3.6 \\
\hline $\mathrm{pH}$ (agua) & 5.2 & 5.5 & 5.7 & 5.3 & 5.2 & 5.5 & 5.6 & 5.7 \\
\hline $\mathrm{pH}(\mathrm{KCl})$ & 4.2 & 4.4 & 4.5 & 4.2 & 4.3 & 4.4 & 4.6 & 4.7 \\
\hline Total $\mathrm{C}\left(\mathrm{g} \mathrm{kg}^{-1}\right)$ & 212 & 69 & 23 & 59 & 64 & 48 & 45 & 21 \\
\hline Total N $\left(\mathrm{g} \mathrm{kg}^{-1}\right)$ & 5.5 & 2.5 & 0.9 & 1.8 & 1.7 & 1.3 & 1.2 & 0.7 \\
\hline $\mathrm{C} / \mathrm{N}$ & 39 & 27 & 25 & 32 & 37 & 38 & 37 & 29 \\
\hline $\mathrm{P}$ (Olsen) (mg kg $\left.{ }^{-1}\right)$ & 19 & 5 & 3 & 6 & 7 & 9 & 5 & 3 \\
\hline $\mathrm{K}\left(\mathrm{mg} \mathrm{kg}{ }^{-1}\right)$ & 305 & 90 & 16 & 43 & 71 & 35 & 37 & 19 \\
\hline $\mathrm{Ca}\left(\mathrm{mg} \mathrm{kg}^{-1}\right)$ & 3,490 & 740 & 103 & 401 & 566 & 270 & 228 & 151 \\
\hline $\operatorname{Mg}\left(\mathrm{mg} \mathrm{kg}^{-1}\right)$ & 250 & 62 & 8 & 41 & 53 & 36 & 18 & 12 \\
\hline $\mathrm{Na}\left(\mathrm{mg} \mathrm{kg}^{-1}\right)$ & 72 & 45 & 17 & 21 & 44 & 20 & 37 & 36 \\
\hline $\mathrm{Fe}\left(\mathrm{mg} \mathrm{kg}^{-1}\right)$ & 1,140 & 475 & 165 & 375 & 354 & 344 & 254 & 250 \\
\hline $\operatorname{Mn}\left(\mathrm{mg} \mathrm{kg}^{-1}\right)$ & 304 & 23 & 11 & 17 & 51 & 32 & 9 & 17 \\
\hline $\mathrm{Cu}\left(\mathrm{mg} \mathrm{kg}^{-1}\right)$ & 10.7 & 5.0 & 2.9 & 2.5 & 2.9 & 2.9 & 4.7 & 4.8 \\
\hline $\mathrm{Zn}\left(\mathrm{mg} \mathrm{kg}^{-1}\right)$ & 19.9 & 3.4 & 1.0 & 3.3 & 4.0 & 2.6 & 2.7 & 1.6 \\
\hline $\mathrm{S}\left(\mathrm{mg} \mathrm{kg}^{-1}\right)$ & 17.9 & 10.9 & 6.3 & 8.8 & 12.1 & 6.7 & 9.1 & 12.5 \\
\hline $\mathrm{B}\left(\mathrm{mg} \mathrm{kg}^{-1}\right)$ & 1.0 & 0.5 & 0.4 & 0.6 & 0.7 & 0.6 & 0.3 & 0.2 \\
\hline $\mathrm{Al}$ (extractable) $\left(\mathrm{mg} \mathrm{kg}^{-1}\right)$ & 590 & 1,660 & 1,020 & 1,250 & 1,060 & 990 & 2,130 & 1,610 \\
\hline $\begin{array}{l}\mathrm{Al} \text { (exchangeable) }(\mathrm{cmol}+ \\
\left.\mathrm{kg}^{-1}\right)\end{array}$ & 0.3 & 0.6 & 0.4 & 1.0 & 0.7 & 0.6 & 0.8 & 0.4 \\
\hline $\begin{array}{l}\text { Sum of basis } \\
\left(\mathrm{cmol}+\mathrm{kg}^{-1}\right)\end{array}$ & 20.6 & 4.6 & 0.7 & 2.5 & 3.6 & 1.8 & 1.5 & 1.1 \\
\hline Aluminum saturation $(\%)$ & 1.4 & 12.1 & 38.0 & 27.3 & 15.4 & 23.5 & 33.3 & 29.8 \\
\hline
\end{tabular}

The lower gravimetric water content in the soil scarified can be explained by changes in bulk density of the soil (Figure 3) and its consequent effect on porosity. However, the amount of water in volume is similar in soils with and without scarification, with no potential water deficit being observed at the surface, which may occur during the summer (considering maximum temperatures $>30^{\circ} \mathrm{C}$ ). The variation of the soil moisture within the gap may be explained by the opening of the canopy and direct exposure to solar radiation (Dalsgaard, 2007). There was a trend towards a higher volumetric water content in when comparing scarified areas compared to other undisturbed areas (Gastadello et al., 2007), and the same happens gaps with undisturbed forest, but in a trial without scarification (Gray et al., 2002). These changes are due to precipitation falling directly on areas without tree cover, since there is no canopy interception or loss caused by the water consumption of vegetation (Lukac and Godbold, 2011), although this varies according to weather and topography.

The higher soil bulk density in scarified areas compared to the undisturbed forest is explained by a change of stratum (going from a finer textured soil to a grittier one, with lower content of organic matter) and to an eventual compaction caused by the traffic of the machine during scarification. The differences between locations in gaps can be explained by natural variation of soil and differences of ground displacement quantity 
caused by bulldozer intervention, which had increased activity in larger gaps (having a major traffic) moving and mixing larger quantities of soil than in medium and small gaps. Hope (2007) also found an increase in bulk density caused by scarification with different methods, a year after intervention in a spodosol. Moreover, the higher resistance to penetration in the scarified area does not reach values that could be considered restrictive to plants (> $2 \mathrm{MPa}$, Horn and Fleige 2009) and, like bulk density, the differences between scarified areas can be attributed to the variability of soil.

The change of chemical-nutritional levels of the soil located between the undisturbed forest and the scarified area is evident, as expected, since the stratum with higher nutrient content was removed (Table 2), which was mainly the first $10 \mathrm{~cm}$ deep. The scarified soil presents moderate to low nutrient levels (Table 2), with intermediate levels of organic matter and high aluminum saturation; the elements found in lower amounts are nitrogen, potassium, magnesium and phosphorus, and the sum of bases is also strongly diminished. The best nutrient levels are achieved through higher contents of organic matter, and its decrease is an assumed consequence of the silvicultural intervention (Aoyama et al., 2011). Still, its effect on a stratified soil as in the case of this study may be more evident in comparison to others (Thiers, 2004), considering that there is no continuity in the transition horizons.

These results are consistent with the findings of Jiménez et al. (2008), who reported a decrease in the levels of nitrogen and carbon in a forest of Pinus ponderosa Dougl. as a consequence of scarification of the first $10 \mathrm{~cm}$ depth in a loamy Alfisol. Gastadello et al. (2007) also observed decreased levels of nitrogen, calcium, magnesium and phosphorus in scarified areas of a spodosol, which exposed a B horizon of sandy loam.

Table 3. Growth parameters (mean \pm standard deviation) of Nothofagus nervosa plantation set to 11 months, in gaps of different sizes.

\begin{tabular}{lccc}
\hline \multirow{2}{*}{\multicolumn{1}{c}{ Parameter }} & \multicolumn{3}{c}{ Gap size } \\
\cline { 2 - 4 } & $\begin{array}{c}\text { Small } \\
\left(150-300 \mathrm{~m}^{2}\right)\end{array}$ & $\begin{array}{c}\text { Medium } \\
\left(300-600 \mathrm{~m}^{2}\right)\end{array}$ & $\begin{array}{c}\text { Large } \\
\left(600-1,000 \mathrm{~m}^{2}\right)\end{array}$ \\
\hline Canopy openness (\%) & $33 \pm 12$ & $37 \pm 8$ & $48 \pm 8$ \\
Total light (mol m $\left.{ }^{-2} \mathrm{~d}^{-1}\right)$ & $18 \pm 8$ & $22 \pm 4$ & $28 \pm 7$ \\
Survival (\%) & $98 \pm 3 \mathrm{a}$ & $96 \pm 3 \mathrm{a}$ & $96 \pm 3 \mathrm{a}$ \\
Total height (cm) & $40 \pm 7 \mathrm{a}$ & $38 \pm 5 \mathrm{~b}$ & $38 \pm 5 \mathrm{ab}$ \\
Height increment* $(\mathrm{cm})$ & $20 \pm 5 \mathrm{a}$ & $15 \pm 6 \mathrm{~b}$ & $17 \pm 6 \mathrm{~b}$ \\
Root collar diameter $(\mathrm{mm})$ & $4,6 \pm 0,6 \mathrm{~b}$ & $4,7 \pm 0,4 \mathrm{~b}$ & $5,2 \pm 0,9 \mathrm{a}$ \\
Volume $\left(\mathrm{cm}^{3}\right.$ per plant) & $5,0 \pm 2,2 \mathrm{ab}$ & $4,5 \pm 2,2 \mathrm{~b}$ & $5,5 \pm 2,6 \mathrm{a}$ \\
\hline
\end{tabular}

Different letters indicate significantly different in each parameter considering the size of the clear $(p<0.05) . *$ Increase in height since its establishment. 


\subsection{Growth behaviour of Nothofagus nervosa plantations in the gaps}

The absence of natural regeneration one year after the intervention may be the caused by the seeding and dormancy periods, and the environmental conditions (Donoso, 1993). The regenerative dynamic of Nothofagus spp. in the Andes is catastrophic mode (Veblen and Ashton, 1978; Veblen et al., 1981) and the scarification performed resembles the conditions after natural disturbance, therefore it is likely that a new natural regeneration may occur in the future. Preliminary observations in this area show evidence of natural regeneration of $N$. nervosa and $N$. dombeyi in the second growing season after scarified but not of weeds or Chusquea spp. (Reyes et al., 2013).

Eventhough the $N$. nervosa plantation presents a high survival after 11 months of being established, its growth is moderate compared to other sites. For the first year in Valdivia Province, there are growth records of $6.0 \mathrm{~mm}$ in diameter and $52 \mathrm{~cm}$ in height in the Central Valley and growht of $8.4 \mathrm{~mm}$ in diameter and $69 \mathrm{~cm}$ in height in the Coastal Range (Donoso et al., 1999); also height growht $>50 \mathrm{~cm}$ (Donoso et al., 2006), and height growht between 60 and $70 \mathrm{~cm}$ in the Valdivian Andes $(650 \mathrm{~m}$ asl) (Donoso et al., 2009). Still, the sites in this study have a more restrictive climate, with plants remaining five to six months under the snow. Differences in plant growth between different sized gaps can be caused by changes in the availability of light (i.e. canopy opening and light transmission) rather than to differences in the characteristics of the soil. In smaller sized gaps the plant growth focuses on reaching height in search of light availability (development presents etiolated traits). In contrast, larger gaps get adequate light therefore growth is focused on diameter. Even if the volume of the plants is similar in both situations, they grow less vigorously in smaller gaps. Nothofagus nervosa is semi-tolerant to shade, being favoured by partial shade conditions instead of open areas (Veblen et al., 1981; Donoso et al., 2006). In this study, the best development occurs in large gaps, although its opening is around 50\%, equivalent to partial shade conditions.
Nutritionally, plants located closer to areas with an accumulation of removed soil, may have access to those nutrients in a shorter period. Gastadello et al. (2007) reports that the low nutrient supply in the scarified area can affect foliar nutrient concentration in plants while they continue in a growth stage, a situation that could also happen to the $N$. nervosa plantation in the near future.

\subsection{Implication for management}

The physical properties (Figures 1 and 3) and the nutrient offer (Table 2) obtained in the scarified area, are still suitable for $N$. nervosa if the natural distribution of the species is considered, although stand productivity will probably be lower when compared to other areas (Donoso et al., 1993). While aluminum saturation levels are very high and may pose a risk of toxicity affecting the root development of many plants (Álvarez et al., 2005), N. nervosa has developed naturally in these soils. Therefore, it should not be a difficulty for its establishment.

By scarifying the upper mineral soil and the reserve contained in the litter are removed, but not extracted from the stand. Indirect and passive reuse of this material could be considered, as reported by Aoyama et al. (2009) who replaced the soil that had been removed from the scarified area, waiting for one year to prevent possible outbreak of bamboos. As a result, soil replacement improved soil moisture and nutrient availability, and moreover, an improved performance was observed in the regeneration.

There is also a question of whether the depth of scarification is appropriate or might be decreased. Considering that the aim of this intervention is to eliminate C. culeou from root, observations on the depth of the the root system would be needed which is mainly found in the top soil (Pearson et al., 1994). The decrease of the scarifying depth would cause less alteration on the physical and chemical properties of the soil. On the other hand, these are deep soils; therefore, there is still a large volume of soil available 
for root development (with reduced fertility) after the scarification. Since it is a volcanic soil strata, the differences between the superficial and subsuperficial layers is evident and they should be considered in silvicultural management.

\section{Conclusions}

Scarification decreases soil quality for plant growth compared to undisturbed forest. However, it does not decrease the amount of water contained in the soil surface. Bulk density and penetration resistance are higher in the scarified soil mainly due to the change of edafic stratum, without reaching limiting values for the development of Nothofagus spp. plants. The nutrient supply of the scarified soil is lower when compared to the undisturbed forest. There are variations between scarified areas that may be caused by both the intensity of intervention and natural variation of the soil. The plantation of $N$. nervosa has a good survival, but with moderate growth. On the other hand, it should be noted that there was no species competition from Chusquea spp. and other weed after scarification, which must be recognized as a considerable advantage for established plants. However, further monitoring of the plantation development is needed, for a longer period of time.

\section{Acknowledgements}

We would like to thank the research projects Fondo de Investigación del Bosque Nativo 042/2010 (CONAF) and FONDEF D07I1034 who funded this research, and Forestal Carranco Neltume SA for providing the facilities. This work was realized under Master in Sciences mention Forest Resources program, from Faculty of Forest Sciences and Natural Resources, Universidad Austral de Chile.

\section{References}

Álvarez, E., Fernández-Marcos, M., Monterroso, C., Fernándes-Sanjurjo, M. 2005. Application of aluminium toxicity indices to soils under various forest species. Forest Ecology and Management. 211, 227-239.

Aoyama, K., Yoshida, T., Kamitani, T. 2009. An alternative of soil scarification treatment for forest restoration: effects of soil replacement. Journal of Forest Research.14, 58-62.

Aoyama, K., Yoshida, T., Harada, A., Noguchi, M., Miya, H., Shibata H. 2011. Changes in carbon stock following soil scarification of non-wooded stands in Hokkaido, northern Japan. Journal of Forest Research. 16, 35-45.

Bustos, F., González, M., Donoso, P.J., Gerding, V., Donoso, C., Escobar, B. 2008. Efectos de distintas dosis de fertilizante de liberación controlada (Osmocote ${ }^{\circledR}$ ) en el desarrollo de plantas de coigüe, raulí y ulmo. Bosque. 29(2), 155-161.

CIREN (Centro de Información de Recursos Naturales, CL). 2001. Estudio Agrológico X Región. Descripciones de suelos, materiales y símbolos. Tomo I. Centro de Investigación de Recursos Naturales, Chile, 199 p.

Dalsgaard, L. 2007. Above and below ground gaps : the effects of a small canopy opening on throughfall, soil moisture and tree transpiration in Suserup Skov, Denmark. Ecological Bulletins. 52, 81-102.

Donoso, C. 1981. Tipos Forestales de los Bosques Nativos de Chile. Documento de Trabajo N ${ }^{\circ} .38$. CONAF, PNUD-FAO, Chile, 70 p.

Donoso C. 1993. Bosques Templados de Chile y Argentina; Variación, estructura y dinámica. Editorial Universitaria, Santiago, Chile, 484 p. 
Donoso, C., Lara, A. 1995. Utilización de los Bosques Nativos en Chile: Pasado, Presente y Futuro. In: J. Armesto , C. Villagrán, M. Arroyo (eds). Ecología de los bosques nativos de Chile. Editorial Universitaria, Santiago, Chile, pp: 363-404.

Donoso, P., González, M., Escobar, B., Basso, I., Otero, L. 1999. Viverización y plantaciones de raulí, roble y coihue. In: C. Donoso, A. Lara (eds). Silvicultura de los bosques nativos de Chile. Universitaria, Santiago, Chile, pp: 177-244.

Donoso, P., Donoso, C., Marchelli, P., Gallo, L., Escobar, B. 2006. Nothofagus nervosa (Phil.) Dim. et Mil. Otros nombres científicos usados: Nothofagus obliqua, Nothofagus procera. Raulí. In: C. Donoso (ed). Las especies arbóreas de los bosques templados de Chile y Argentina, autoecología. Marisa Cuneo Ediciones, Valdivia, Chile, pp: 448-461.

Donoso, P., Soto, D., Gerding, V. 2009. Efectos de la poda de tallo y fertilización de liberación controlada en vivero sobre el comportamiento de plántulas de Nothofagus nervosa en terreno. Bosque. 30(1), 48-53.

Frazer, G., Canham, C., Lertzman, K. 1999. Gap Light Analyzer (GLA), version 2.0: Imaging Software to Extract Canopy Structure and Gap Light Indices from True-colour fisheye Photographs. Simon Fraser University, Burnaby, BC, and the Institute of Ecosystem Studies, Millbrook, New York.

Gastaldello, P., Ruel, J.C., Paré, D. 2007. Microvariations in yellow birch (Betula alleghaniensis) growth conditions after patch scarification. Forest Ecology and Management. 238, 244-248.

Gray, A.N., Spies, T.A., Ester, M.J. 2002. Microclimate and soil moisture responses to gap formation in coastal Douglas fir forests. Canadian Journal of Forest Research. 32, 332-343.
Haining, R. 2003. Spatial data analysis theory and practice. Cambridge Univ. Press, U.K., 468 p.

Hille, M., den Ouden, J. 2004. Improved recruitment and early growth of Scots pine (Pinus sylvestris L.) seedlings after fire and soil scarification. European Journal of Forest Research. 123, 213-218.

Hope, G. 2007. Changes in soil properties, tree growth, and nutrition over a period of 10 years after stump removal and scarification on moderately coarse soils in interior British Columbia. Forest Ecology and Management. 242, 625-635.

Horn, R., Fleige, H. 2009. Risk assessment of subsoil compaction for arable soils in Northwest Germany at farm scale Soil and Tillage Research. 102, 201208.

INIA (Instituto Nacional de Investigaciones Agropecuarias, CL). 1989. Mapa agroclimático de Chile. Ministerio de Agricultura, Santiago, Chile, $221 \mathrm{p}$.

Jiménez, A., Stromberger, M., Shepperd, W. 2008. Soil scarification and wildfire interactions and effects on microbial communities and carbon. Soil Science Society of America Journal 72, 111-118.

Karlsson, M., Nilsson, U. 2005. The effects of scarification and shelterwood treatments on naturally regenerated seedlings in southern Sweden. Forest Ecology and Management. 205, 183-197.

Lal, R., Shukla, M. 2004. Principles of Soil Physics. Marcel Dekker. New York, 688 p.

Lukac, M., Godbold, D. 2011. Soil Ecology in Northern Forests : A Belowground View of a Changing World. Cambridge University Press, New York, 268 p.

Nyland, R. 2002. Silviculture concepts and applications. McGraw-Hill, New York, USA, 631 p. 
Örlander, G., Egnell, E., Albrektson, A. 1996. Longterm effects of site preparation on growth in Scots pine. Forest Ecology and Management. 86, 2737.

Otero, L. 2006. La huella del fuego: historia de los bosques nativos poblamiento y cambios en el paisaje del sur de Chile. Pehuén, Santiago, Chile, $168 \mathrm{p}$.

Palviainen, M., Finér, L., Mannerkoski, H., Piirainen, S., Starr, M. 2005. Changes in the above-and below-ground biomass and nutrient pools of ground vegetation after clear-cutting of a mixed boreal forest. Plant and Soil. 275, 157-167.

Pearson, A., Pearson, P., Gomez, I. 1994. Biology of the bamboo Chusquea culeou (Poaceae: Bambusoideae) in southern Argentina. Plant Ecology. 111, 93-126.

Piirainen, S., Finer, L., Mannerkoski, H., Starr, M. 2007. Carbon, nitrogen and phosphorus leaching after site preparation at a boreal forest clear-cut area. Forest Ecology and Management. 243, 1018.

Resco de Dios, V., Yoshida, T., Iga, Y. 2005. Effects of topsoil removal by soil-scarification on regeneration dynamics of mixed forests in Hokkaido, Northern Japan. Forest Ecology and Management. 215, 138-148.

Reyes, J., Thiers, O., Gerding, V., Soto, D.P. 2013. Recuperación de bosques con Nothofagus spp. en Los Andes del sur de Chile: uso de la escarificación del suelo como técnica facilitadora para la regeneración. Revista Bosque Nativo. 52, 45-50.

Sadzawka, A., Carrasco, M., Grez, R., Mora, M., Flores, H., Neaman, A. 2006. Métodos de análisis recomendados para los suelos de Chile. Instituto de investigaciones Agropecuarias, Santiago, Chile, $164 \mathrm{p}$.
Schlatter, J., Grez, R., Gerding, V. 2003. Manual para el reconocimiento de suelos. Universidad Austral de Chile, Valdivia, Chile, 114 p.

Thiers, O. 2004. Roble (Nothofagus blique)Sekundärwäder in Zentral- und Südchile: Bestimmung der für die Bestandesproduktivität wichtigen Standortsfaktoren. Freiburger Bodenkundliche Abhandlungen $\mathrm{N}^{\circ} 42.170 \mathrm{p}$

Veblen, T., Ashton, D. 1978. Catastrophic influences on the vegetation of the Valdivian Andes. Plant Ecology. 36, 149-167.

Veblen, T., Donoso, C., Schlegel, F., Escobar, B. 1981. Forest dynamics in southcentral Chile. Journal of Biogeography. 8, 211-247.

Veblen, T., Donoso, C., Kitzberger, T., Rebertus, A. 1996. Ecology of Southern Chilean and Argentinean Nothofagus forest. In: T. Veblen, R. Hall, J. Read (eds). The Ecology and Biogeography of Nothofagus forest. Yale University Press, New Haven, pp: 293-353.

Wurtz, T., Zasada, J. 2001. An alternative to clearcutting in the boreal forest of Alaska: a 27year study of regeneration after shelterwood harvesting. Canadian Journal of Forest Research. 31, 999-1011.

Yoshida, T., Iga, Y., Ozawa, M., Noguchi, M., Shibata, H. 2005. Factors influencing early vegetation establishment following soil scarification in a mixed forest in northern Japan. Canadian Journal of Forest Research. 35, 175-188.

Zaczek, J. 2002. Composition, diversity, and height of tree regeneration, 3 years after soil-scarification in a mixed-oak shelterwood. Forest Ecology and Management. 163, 205-215.

Zar, J. 2010. Biostatistical Analysis (5th Edition). Upper Saddle River, NJ, USA, Prentice Hall, $960 \mathrm{p}$. 